\title{
Effects of ethanol extract of Mucuna pruriens leaves on the lipid profile and serum electrolytes of rats
}

\author{
*Enechi, O. C. and Ozougwu, V. E. O. \\ Department of Biochemistry, University of Nigeria, Nsukka.
}

\begin{abstract}
The effects of ethanol extract of Mucuna pruriens leaves on the lipid profile and serum electrolytes of rats after a two-week treatment were investigated. Preliminary phytochemical analysis of the leaves of Mucuna pruriens revealed the presence of alkaloids, saponins, flavonoids, tannins and glycosides while cyanogenic glycosides were not detected. Oral treatment of rats with the aqueous leaf extract $(400 \mathrm{mg} / \mathrm{kg}$ body weight and $800 \mathrm{mg} / \mathrm{kg}$ body weight) for 7 days and 14 days respectively evoked significant $(P<0.05)$ decreases in the mean body weights of rats. However, there were no significant changes in the relative liver weights of the rats compared to the control animals. There were also significant $(p<0.05)$ decreases in the levels of total serum cholesterol, low density lipoprotein (LDL) cholesterol, free fatty acids, serum phospholipids as well as serum triacylglycerol but there was a significant increase $(p<0.05)$ in the levels of high density lipoprotein $(H D L)$ cholesterol compared to the controls. Analysis also revealed that the ethanol extract of Mucuna pruriens leaves brought about significant changes ( $p<0.05)$ in the concentrations of the principal serum cations $\left(\mathrm{Na}^{+}\right.$and $\left.\mathrm{K}^{+}\right)$ as well as serum chloride concentrations at the same dose levels and duration. However, the serum bicarbonate ions concentration was not affected. These findings show that the ethanol extract of Mucuna pruriens exhibits hypolipidaemic effect on experimental animals and suggest that the extract may be beneficial and of clinical importance to individuals at risks of cardiovascular problems.
\end{abstract}

Key Words: Hypolipidaemic effect, Mucuna pruriens, cardiovascular disorders.

\section{Introduction}

Medicinal plants are now getting more attention than ever because they have potential of myriad benefits to society, especially in the line of medicine and pharmacology (Safowora,1993). At present, the world Health Organization is taking an official interest in herbal medicines in order to facilitate its aim of making health available for all. Traditional medicine has remained popular in all regions of the world, especially for the developing countries due to accessibility, affordability and the advantage of having multiple efficacy and minimal side effects (UNESCO, 1998). There is worldwide epidemic of cardiovascular diseases, which are associated with a number of pathologies including dyslipidemia (Eckel et al., 2004). Increased plasma lipids such as cholesterol and triglycerides are important risk factors in cardiovascular diseases.

Mucuna pruriens (velvet beans) is an unconventional legume commonly found in the tropical regions of Africa, India and West Indies. (Taylor, 2005). The leaves are consumed for their nutritional value and are also used in folk medicine as a therapy for various diseases such as diabetes, arthritis, dysentery, infertility, obesity and cardiovascular disorders (Nadkaru, 2001). The leaves and seeds have shown significant aphrodisiac, antispasmodic, anticataleptic, antiepileptic, anti-diabetic, antimicrobial, anti-inflammatory, pain-relieving and fever-reducing activities from various clinical researches with animals (Amin et al., 1996; Hussain and Manyam, 1997; Sathiyanaryanan et al., 2007; Majekodunmi et al 2011; Champasingh et al., 2011; Lampariello et al.,2012). The nutritional and toxicological potentials of the seeds have been evaluated (Enechi et al., 2011). The seeds are also implicated in the treatment of Parkinson's disease (Hussain and Manyam, 1997). This study was therefore undertaken to assess the effects of Mucuna pruriens leaf extract on serum lipids and electrolytes with a view to giving a scientific backbone to the traditional medicinal usage of the plant in the management of obesity and its associated complications such as cardiovascular disorders.

\section{Materials And Methods}

\section{Chemicals/Reagents}

Total lipids, total cholesterol, and triglycerides kits are products of Randox Chemicals Hall, England. All other chemicals/reagents are of analytical grade and were obtained from BDH Limited Poole, England.

\section{Plant material}

The leaves of Mucuna pruriens were collected from Nsukka, Enugu State Nigeria and identified by Dr. Uche Nzekwe of the Department of Plant Science and Biotechnology, University of Nigeria, Nsukka where a voucher specimen is also retained. 


\section{Extraction}

Fresh leaves of Mucuna pruriens $(500 \mathrm{~g})$ were air died for seven days under atmospheric conditions and pulverized with the aid of an electric blender. The pulverized material was macerated in $70 \%$ ethanol to give an extract that was filtered. The filtrate was concentrated using a rotary evaporator to yield a vicious slurry with a percentage recovery of $8 \%$.

\section{Acute Toxicity Test}

This was done using the Lorke's method (Lorke, 1983). A total of 25 albino rats (Wistar strain) weighing between $100-150 \mathrm{~g}$ were fasted overnight although with access to tap water. They were divided into five groups of five rats each. Four groups were given different doses of the extract in the following order: 200, $500,2000,5000 \mathrm{mg} / \mathrm{kg}$ body weight of the rats while the fifth group (control) received only normal saline. The rats were observed for 12 hours for any lethality or signs of overt toxicity.

\section{Preliminary Phytochemical Analysis}

The phytochemical tests on the Mucuna pruriens ethanol extract for the presence of alkaloids, saponins, flavonoide tannins, glycosides and cyanogenic glycosides were carried out as described by Harboume (1973)

\section{Animal Treatment}

Twenty four albino rats (Wistar strain) of both sexes weighing averagely $150 \mathrm{~g}$ were divided into three groups of eight rats each. They were allowed free access to water and standard diet. Group 1 served as the control and were treated with normal saline $(0.4 \mathrm{ml} / 100 \mathrm{~g}$ body weight). While group 2 and group 3 were daily administered $400 \mathrm{mg} / \mathrm{kg}$ body weight and $800 \mathrm{mg} / \mathrm{kg}$ body weight of the plant extract respectively. After seven days, half of the animals in each group were sacrificed by chloroform anesthesia while the remaining half were sacrificed after 14 days of treatment. All administrations were orally by gastric intubation. Blood was collected by cardiac puncture and allowed to clot, centrifuged at $3000 \mathrm{rpm}$ for $15 \mathrm{mins}$ and the serum aspirated. The livers of the animals in each case were excised, washed in normal saline, allowed to dry and then weighed.

\section{Determination of Serum Indices of Lipid Metabolism}

The following serum indices of lipid metabolism were determined spectrophotometrically using enzymatic colometric assay kits as follows:

\section{Determination of Total Serum Cholesterol Concentration}

Total serum cholesterol was determined according to the method of Stein (1987) using Randox kits.

Determination of low density lipoprotein (LDL) cholesterol level

Low density cholesterol level was determined according to the method of Assmann et al. (1976).

\section{Determinaton of high density lipoprotein (HDL) cholesterol level}

High density lipoprotein cholesterol level was determined according to the method of Albers et al. (1978) using QCA commercial kits.

Determination of free fatty acids.

Total serum free fatty acids was determined according to the method of Tietz (1990) using Randox kits.

Determination of Serum Phospholipid level

Serum phospholipid level was determined according to the method of Tietz (1990) using Randox kits.

\section{Determination of Serum Triacylgycerol}

The serum triglyceride level was determined as described by method of Tietz (1990) using Randox kits.

\section{Determination of Serum Potassium and sodium ion Concentrations}

Serum concentrations of these ions were determined using flame photometry according to AOAC (1984).

Determination of Serum Bicarbonate and Chloride ion concentrations

Serum concentrations of these ions were determined using the method described by Tietz (1990). 


\section{Statistical analysis}

The data obtained in this study were evaluated using the one-way analysis of variance (ANOVA) test between two mean groups, control and test groups, followed by student's t-test. Significant levels were at $p<0.05$. Values were expressed as means \pm standard deviation $(\mathrm{SD})$.

\section{Acute Toxicity Test}

\section{Results And Discussion}

Oral administration of the ethanol leaf extract of Mucuna pruriens produced no gross behavioral and/or physical changes in lethality at doses up to $5000 \mathrm{mg} / \mathrm{kg}$ body weight. The doses used in this study are therefore considered to be toxicologically safe.

\section{Phytochemical Analysis}

The results of phytochemical analysis are presented in Table 1 .

Table 1: Phytochemical Screening of Mucuna Pruriens

Key:

\begin{tabular}{|l|l|}
\hline Alkaloids & + \\
\hline Saponins & + \\
\hline Flavoniods & + \\
\hline Tannins & + \\
\hline Glycosides & + \\
\hline Cyanogenic glycoside & ND \\
\hline
\end{tabular}

$$
\begin{array}{lll}
+ & = & \text { Presence of component tested } \\
\mathrm{ND} & = & \text { Not detected }
\end{array}
$$

Phytochemical analysis revealed the presence of alkaloids, saponins, flavoniods, tannins and glycosides as presented in Table 1 above. These bioactive compounds detected in the extract are known to have a variety of pharmacological activities (Trease and Evans, 1983).

Table 2: Effect of ethanol extract of Mucuna pruriens on mean change in body weights of rats.

\begin{tabular}{|l|l|l|}
\hline \multirow{2}{*}{ Treatment } & \multicolumn{2}{|l|}{ Mean change in body weights (g) } \\
\cline { 2 - 3 } & $\mathbf{7}$ Days & 14 Days \\
\hline (a). Control (Normal saline) & $82.25 \pm 4.16$ & $90.2 \pm 11.63$ \\
\hline (b). Group 1 (400mg/kg b.w) & $81.23 \pm 9.19$ & $91.6 \pm 6.00$ \\
\hline (c). Group II (800mg/kg b.w) & $83.35 \pm 6.71$ & $* 63.3 \pm 7.42$ \\
\hline
\end{tabular}

Values represent mean \pm standard deviation. *Significant at $\mathrm{P}<0.05$.

Table 2 shows that ethanol extract of Mucuna pruriens leaf elicited no significant change in the body weights of the animals when challenged with dose of $400 \mathrm{mg} / \mathrm{kg}$ for the period under investigation. However, there was a significant $(\mathrm{P}<0.05)$ change in body weights of the animals when challenged with higher doses of the extract $(800 \mathrm{mg} / \mathrm{kg})$ for 14 days when compared to the control animals. This implies that the extract has effect on the body weights of the animals.

Table 3: Effect of ethanol extract of Mucuna pruriens leaf on the relative liver weights of rats.

\begin{tabular}{|l|l|l|}
\hline \multirow{2}{*}{ Treatment } & Relative liver weight (mean \pm S.D) $\mathbf{~ g / k g )}$ & $\mathbf{1 4}$ Days \\
\cline { 2 - 3 } & 7 Days & $3.08 \pm 0.34$ \\
\hline Control (normal saline) & $3.73 \pm 0.13$ & $3.00 \pm 0.22$ \\
\hline Group I 400mg/kg b.w. & $4.00 \pm 0.73$ & $3.33 \pm 0.34$ \\
\hline Group II 800mg/kg b.w & $3.00 \pm 0.68$ & \\
\hline
\end{tabular}

Table 3 shows that there were no significant $(\mathrm{P}<0.05)$ changes in the relative liver weights of the rats when compared to the controls. This implies that the plant extract did not exert any gross pathological effects on the livers of the animals.

Table 4: Effect of ethanol extract of Mucuna pruriens leaf on total serum cholesterol level in rats.

\begin{tabular}{|l|l|l|}
\hline \multirow{2}{*}{ Treatment } & Total serum cholesterol level (mean \pm S.D) \\
\cline { 2 - 3 } & 7 Days & 14 Days \\
\hline Control (normal saline) & $431.87 \pm 25.96$ & $369.71 \pm 37.97$ \\
\hline Group I 400mg/kg b.w. & $* 307.75 \pm 43.85$ & $* 201.37 \pm 39.97$ \\
\hline Group II 800mg/kg b.w & $* 272.29 \pm 28.17$ & $* 201.36 \pm 29.97$ \\
\hline
\end{tabular}


Values represent mean \pm standard deviation.

*Significant at $\mathrm{P}<0.05$

Table 4 above shows a significant $(\mathrm{P}<0.05)$ decrease in the mean total cholesterol levels in the experimental animals when compared to the control animals.

Table 5: Effect of ethanol extract of Mucuna pruriens leaf on serum low density lipoprotein cholesterol levels in rats.

\begin{tabular}{|l|l|l|}
\hline \multirow{2}{*}{ Treatment } & Serum low density lipoprotein cholesterol levels (mean \pm S.D) $(\mathbf{m g} / \mathbf{d l})$ \\
\cline { 2 - 3 } & 7 Days & $196.49 \pm 15.90$ \\
\hline Control (normal saline) & $201.57 \pm 19.46$ & $* 125.15 \pm 20.05$ \\
\hline Group I 400mg/kg b.w. & $* 132.75 \pm 17.25$ & $* 115.41 \pm 20.37$ \\
\hline Group II 800mg/kg b.w & $* 129.25 \pm 22.50$ & Days \\
\hline
\end{tabular}

Values represent mean \pm standard deviation.

*Significant at $\mathrm{P}<0.05$

Table 5 above shows a significant $(\mathrm{P}<0.05)$ decrease in the mean levels of low density lipoprotein cholesterol in the experimental animals when compared to the control animals.

Table 6: Effect of ethanol extract of Mucuna pruriens leaf on serum high density lipoprotein cholesterol levels in rats.

\begin{tabular}{|l|l|l|}
\hline \multirow{2}{*}{ Treatment } & \multicolumn{2}{|l|}{ Serum high density lipoprotein cholesterol levels (mean \pm S.D) (mg/dl) } \\
\cline { 2 - 3 } & 7 Days & 14 Days \\
\hline Control (normal saline) & $86.22 \pm 12.11$ & $92.34 \pm 14.40$ \\
\hline Group I 400mg/kg b.w. & $* 100.25 \pm 13.06$ & $* 122.21 \pm 09.54$ \\
\hline Group II 800mg/kg b.w & $* 115.27 \pm 18.32$ & $* 129.10 \pm 20.21$ \\
\hline
\end{tabular}

Values represent mean \pm standard deviation.

$*$ Significant at $\mathrm{P}<0.05$

Table 6 above shows a significant $(\mathrm{P}<0.05)$ increase in the mean levels of high density lipoprotein cholesterol in the experimental animals when compared to the control animals.

Table 7: Effect of ethanol extract of Mucuna pruriens leaf on serum fatty acid levels in rats.

\begin{tabular}{|l|l|l|}
\hline Treatment & Serum fatty acid levels ( mean \pm S.D) mg/dl \\
\cline { 2 - 3 } & 7 Days & 14 Days \\
\hline Control (normal saline) & $56.68 \pm 5.03$ & $46.33 \pm 8.96$ \\
\hline Group I 400mg/kg b.w. & $* 26.66 \pm 7.43$ & $* 21.48 \pm 8.96$ \\
\hline Group II $800 \mathrm{mg} / \mathrm{kg}$ b.w & $* 24.59 \pm 14.34$ & $* 14.23 \pm 5.76$ \\
\hline
\end{tabular}

Values represent mean \pm standard deviation. * Significant at $\mathrm{P}<0.05$

Table 7 shows significant $(\mathrm{P}<0.05)$ decrease in serum fatty acid levels for the experimental animals when compared to the control animals.

Table 8: Effect of ethanol extract of Mucuna pruriens leaf on serum phospholipid levels.

\begin{tabular}{|l|l|l|}
\hline \multirow{2}{*}{ Treatment } & Serum phospholipid levels (mean \pm S.D mg/dl) \\
\cline { 2 - 3 } & 7 Days & 14 Days \\
\hline Control (normal saline) & $116.89 \pm 21.11$ & $82.26 \pm 25.12$ \\
\hline Group I 400mg $/ \mathrm{kg}$ b.w. & $* 94.71 \pm 11.28$ & $* 60.58 \pm 11.28$ \\
\hline Group II $800 \mathrm{mg} / \mathrm{kg}$ b.w & $* 89.60 \pm 12.50$ & $* 55.47 \pm 12.50$ \\
\hline
\end{tabular}

Values represent mean \pm standard deviation. *Significant at $\mathrm{P}<0.05$

The ethanol extract of Mucuna pruriens leaf exerted a significant $(\mathrm{P}<0.05)$ decrease in the serum phospholipid levels for the experimental animals when compared to the controls. 
Table 9: Effects of ethanol extract of Mucuna pruriens leaf on serum triacylglycerol levels in rat.

\begin{tabular}{|l|l|l|}
\hline \multirow{2}{*}{ Treatment } & Serum Triacylglycerol Levels (mg/dl) \\
\cline { 2 - 3 } & 7 Days & 14 Days \\
\hline Control (normal saline) & $13629 \pm 160.94$ & $195.55 \pm 160.94$ \\
\hline Group I 400mg/kg b.w. & $* 528.00 \pm 111.15$ & $* 660.74 \pm 111.15$ \\
\hline Group II $800 \mathrm{mg} / \mathrm{kg}$ b.w & $* 277.67 \pm 156.67$ & $* 411.52 \pm 156.66$ \\
\hline
\end{tabular}

Values represent mean \pm standard deviation. * Significant at $\mathrm{P}<0.05$

Table 9 shows a significant $(\mathrm{P}<0.05)$ decrease in the mean serum triacylglycerol levels in the experimental groups when compared to the controls. It also shows that the marked decreases exerted by the ethanol extract on the lipid profile of the rats were concentration- dependent.

Table 10: Effect of ethanol extract of Mucuna pruriens leaf on serum electrolytes levels in rats after 7 days

\begin{tabular}{|l|l|l|l|}
\hline \multirow{2}{*}{ Parameters } & \multicolumn{2}{|c|}{ Treatment } \\
\cline { 2 - 4 } & Normal saline & $\begin{array}{l}\text { Extract } \\
\mathbf{4 0 0} \mathbf{~ m g} / \mathbf{k g} \text { b.w. }\end{array}$ & $\begin{array}{l}\text { Extract } \\
\mathbf{8 0 0} \text { mg/kg b.w. }\end{array}$ \\
\hline Potassium $\left(\mathrm{K}^{+}\right)$ & $0.178 \pm 0.04$ & $0.29 \pm 0.11$ & $0.33 \pm 0.15$ \\
\hline Sodium $\left(\mathrm{Na}^{+}\right)$ & $42.20 \pm 4.99$ & $* 35.87 \pm 1.94$ & $* 35.92 \pm 0.10$ \\
\hline Bicarbonate $\left(\mathrm{HCO}^{3-}\right)$ & $47.30 \pm 7.65$ & $48.10 \pm 39.78$ & $48.70 \pm 3.32$ \\
\hline Chloride $\left(\mathrm{Cl}^{-}\right)$ & $1.38 \pm 0.22$ & $1.09 \pm 0.64$ & $1.95 \pm 0.15$ \\
\hline
\end{tabular}

Table 11: Effect of ethanol extract of Mucuna pruriens leaf on serum electrolytes levels in rats after 14 days

\begin{tabular}{|l|l|l|l|}
\hline \multirow{2}{*}{ Parameters } & \multicolumn{2}{|c|}{ Treatment } \\
& \multicolumn{2}{|c|}{} \\
\cline { 2 - 4 } & Normal saline & Extract 400mg/kg & Extract 800mg/kg \\
\hline Potassium $\left(\mathrm{K}^{+}\right)$ & $0.35 \pm 0.02$ & $* 0.80 \pm 0.01$ & $* 0.48 \pm 0.04$ \\
\hline Sodium $\left(\mathrm{Na}^{+}\right)$ & $66.30 \pm 2.68$ & $* 62.35 \pm 0.16$ & $* 63.795 \pm 1.64$ \\
\hline Bicarbonate $\left(\mathrm{HCO}^{3-}\right)$ & $48.36 \pm 2.18$ & $44.63 \pm 3.64$ & $49.73 \pm 3.10$ \\
\hline Chloride $\left(\mathrm{Cl}^{-}\right)$ & $1.65 \pm 0.92$ & $* 3.55 \pm 1.15$ & $* 5.46 \pm 2.033$ \\
\hline
\end{tabular}

Tables 10 and 11 show no significant difference $(p>0.05)$ in the serum concentrations of bicarbonate ions of rats after administration of $400 \mathrm{mg} / \mathrm{kg}$ b.w and $800 \mathrm{mg} / \mathrm{kg}$ b.w extract with respect to the controls. However, there was significant increase in serum chloride concentration $(\mathrm{p}<0.05)$ and decrease in sodium ions concentration after both 7 days and 14 days, when compared to the control. Also, at $400 \mathrm{mg} / \mathrm{kg} \mathrm{b.w} \mathrm{and} 800 \mathrm{mg} / \mathrm{kg} \mathrm{b.w}$ respectively, the extract caused no significant difference $(p>0.05)$ in the potassium and chloride ions concentrations after 7 days while there were significant increases $(p<0.05)$ in the serum concentrations of potassium and chloride ions of rats with respect to the controls after 14 days of administration.

\section{Discussion}

One of the efficient ways of managing the ever increasing cases of hyperlipidemia and its complications such as artherosclerosls and hypertension is diet therapy. This is by the control of the major risk factors such as blood cholesterol and triacylglycerol that predispose to these disorders (Ghasi et al., 2000) Herbal remedies are often used in folk medicine to improve the lipid profile thus preventing cardiovascular diseases (Ostlund, 2002).

The results of this study clearly indicate that the administration of extract of Mucuna pruriens leaves produced hypoliplidemic effect in experimental animals. Phytochemical analysis revealed the presence of flavonoids alkaloid, glycosides, tannins and saponins. Previous studies showed that these phytochemicals acting wholly or partly may be responsible for the lipid-lowering action of some plant extracts (Gaamoussi et al., 2010 ). Flavonoids prevent the oxidation of low-density lipoprotein, lower the blood levels of cholesterol and triglycerides thereby reducing the risk for the development of atherosclerosis (Subramani and Casmir, 2002). Saponins bind with bile salt and cholesterol in the intestinal tract. This binding causes a reduction of blood cholesterol by preventing its reabsorption (Oalienfill and Siddha, 1990). Cardiac glycosides have been used as diuretics and heart tonics due to their beneficial effects on the heart. They act by affecting the availability of intracellular $\mathrm{Ca}^{2+}$ for myocardial contraction (Walter et al., 2002). The hypocholesterolemic effect of the extract may be due to a number of mechanisms including the inhibition of cholesterol biosynthesis; prevention of the oxidation of low-density lipoprotein; conversion of cholesterol into bile acids and inhibition of cholesterol absorption from the intestine due to formation of complexes with compounds such as glycosides and saponins. Furthermore, the result showed that the extract of Mucuna pruriens had some significant effects $(\mathrm{P}<0.05)$ on 
serum electrolytes $\left(\mathrm{Na}^{+}\right.$and $\left.\mathrm{K}^{+}\right)$which are known to play some role in the pathogenesis of cardiovascular disorders (Ezekwesili et al., 2008). The observed hypolipidaemic effect by the extract may be ascribed to the phytochemical constituents of the leaf.

These results suggest that the leaf extract of Mucuna pruriens might be useful in the treatment hyperlipidaemia and its associated complications such as cardiovascular diseases.

\section{References}

[1]. AOAC (1984). Official Methods of Analysis (14 $4^{\text {th }}$ ed) Association of official Analytical chemists. Washington D.C.

[2]. Albers, J. J., Warmick, G. R. and Cheng, M. C. (1978). Determination of high density lipoprotein (HDL) cholesterol. Lipids 13: 926-932.

[3]. Amin, K. M. Y., Khan, M. N., Zillur-Rehman, S.and Khan, N. A. (1996).Sexual function improving effect of Mucuna pruriens in sexually normal male rats. Fitoterapia, 67 (1): 53-58.

[4]. Assman, G., Jabs, H. U., Kohnert, U., Nolte, W. and Schriewer, H. (1984).Determination of low density lipoprotein (LDL) cholesterol. Clinica Chimica Act. 140: 77-83.

[5]. Champatisingh, D., Sahu, P. K., Pal, I. A. and Nanda, G. S. (2011). Anticataleptic and antiepileptic activities of Mucuna pruriens. Indian Journal of Pharmacology.43(2):197-199.

[6]. Ezekwesili, C.N., Obidoa, O. and Nwodo, O.F.C. (2008). Effects of ethanol extract of Acalypha torta leaves on lipid profile and serum electrolytes of Rabbits. Nigerian Journal of Biochemistry and molecular Biology 23(1): 15-19.

[7]. Enechi, O.C., Tufon, E.N. and Ogugua, V.N. (2011). Nutritional and toxicological potentials of Mucuna pruriens seed. Research Journal of Pharmacognosy and Biochemistry, 3(5):241-243.

[8]. Eckel, R.H., York D.A, Rossner S, Hubbard, V. (2004). Prevention conference VII: Obesity, a worldwide epidemic related to heart disease and stroke: Circulation, 110:2968-2975

[9]. .Ghasi,, S., Nwobodo, E. and Ofili, J.O. (2002). Hypocholesterolemic effects of crude extract of leaf of Moringa olerifera lam in high-fat diet fed Wistar rats. J. Ethnopharm. 69:21-25.

[10]. Gaamoussi F., Israeli, N and Lyoussi, B. (2010.) Hypoglycemic and hypolipidemic effects of an aqueous extract of Chemaerops humilis leaves in obese, hyperglycemic and hyperlipidemic meriones shawi rats. Pak. J. Pharm.. 23(2):212-319.

[11]. Hussain, G. and Manyam, B. V. (1997). Mucuna pruriens proves more effective than L-DOPA in Parkinson's disease. Phytotherapy Research 116: 419-423.

[12]. Harborne, J.B. (1973). Phytochemical methods. A guide to modern techniques of plant analysis $2^{\text {nd }}$ ed. $33-80$, Chapman and Hall. U.S.A.

[13]. Lorke, D. (1983). A new approach to practical acute toxicity testing. Arch. in Toxicol., 544:275-289.

[14]. Majekodunmi,S. O., Oyagbemi, A. A., Umukoro, S. and Odeku, O. A.(2011). Evaluation of anti-diabetic properties of Mucuna pruriens seed extract. Asian Pacific Journal of Tropical Medicine, 4(8):632-636.

[15]. Nadkaru K. M. (2001).Indian plants with their medicinal properties and uses. Indian Journal of Chemistry, 48:282-293

[16]. Ostlund, P. E. (2002). Phytosterols in humans. Nutr. 22:533-549.

[17]. Oalienfill, D., Sidhu, G. (1990). Saponins. A useful treatment for Hypercholesteroleamia. European Journal of clinical Nutrition, 44: 79-88.

[18]. Safowora, A. (1993). Medicinal Plants and Traditional Medicine in Africa $2^{\text {nd }}$ ed. Spectrum Books limited, Ibadan, pp 1 - 50.

[19]. Subramani, S., Casimir, C.A. (2002).Flavonoids and antioxidant activity of Georgia grown Vidalia onions. Journal of Agricultural and food chemistry, 50 (19): 5338 -5342.

[20]. Sathiyanaryanan, L. and Arulmozhi, S. (2007). Mucuna pruriens. A comprehensive review. Pharmacognosy Review, 1:157-162.

[21]. Stein E.A. 1987. Lipids, Lipoproteins and Apolipoproteins. In N. W. Treets (Ed) fundamentals of clinical chemistry $3^{\text {rd }}$ Edu, W.B. Sanders Philadelphia pp:470-479.

[22]. Tietz, N.W., 1990. Clinical Guide to Laboratory Test. $2^{\text {nd }}$ Edn, W.B. Saunders company, Philadelphia, U.S.A. pp: 554-556.

[23]. Trease, G.E. and Evans M. C. (1983). Textbook of pharmacognosy, $13^{\text {th }}$ Edn, Bailer Tindal, London. Pp $247-762$

[24]. Taylor, C.N. (2005). The heading power of rain forest Herbs: A guide to understanding and using Herbal Medicines. Garden City. Park, N.Y.

[25]. UNESCO (1997). Promotion of ethnobotany, and sustainable use of plant resources in Africa. Terminal Report, PP 60

[26]. Walter, A.F., Marakis, G.,Morris, A. P., Robindon, P.A. (2002). Promising hypotensive effect of hawthorn extract: a randomized double -blind pilot study of mild essential hypertension. Phytother. Res. 16(1), 48 -54. 